\title{
Magnetic Force Microscopy of Magnetic Recording Media at Low and Elevated Temperatures
}

\author{
Y. Yasui, K. Shimomai, and M. Futamoto \\ Faculty of Science and Engineering, Chuo University, 1-13-27 Kasuga, Bunkyo-ku, Tokyo 112-8551, Japan
}

\begin{abstract}
The recorded magnetization structures of longitudinal and perpendicular recording media were investigated by magnetic force microscopy in a temperature range between -50 and $300{ }^{\circ} \mathrm{C}$. We found that when the sample temperatures are increased, variations in recorded magnetization occur preferentially in regions recorded with shorter bit lengths for longitudinal media. On the contrary, they tend to occur in regions recorded with longer bit lengths for perpendicular media. The behaviors of variations in magnetization structures with heating differ slightly bit by bit even for similar bit lengths.
\end{abstract}

Key words: in-situ observation, magnetic force microscopy, longitudinal media, perpendicular media

\section{冷却・加熱時における磁気記録媒体の MFM 観察}

安井佑介・下舞恵介・二本正昭

中央大学理工学部, 東京都文京区春日 1-13-27（†112-8551）

\section{1. はじめに}

磁気記録の高記録密度化が進み, 記録密度が $100 \mathrm{Gbit} / \mathrm{in}^{2}$ を超え るハードディスクドライブ (HDD) が出荷され始めた. HDDの 高記録密度化に伴い記録ビットの微細化が進行し，従来の面内記 録方式では熱ゆらぎ現象による記録磁化情報の不安定化が問題と なりつつある．高記録密度領域で面内記録に比べて耐熱ゆらぎ性 に優れる垂直記録方式を採用したHDDも実用化され，市場に登場 し始めている．磁気記録の高密度化は今後も継続的に進展するも のと予測され，外部磁界や温度などの環境変化に対するHDDの信 頼性の確保がますます重要となっている，温度などの環境が高密 度磁気記録した媒体の磁化状態に及ぼす影響が調べられ始めてい $3^{1-4)}$.

本研究では，温度が記録磁化状態に及ぼす影響を調べることを 目的として，面内及び垂直磁気記録媒体の記録磁化状態を磁気力 顕微鏡 $(\mathrm{MFM})$ で観察した. HDD 記録媒体のビット形態を，温 度を制御しながらその場観察を行い，変化の様子を調べた。

\section{2. 実験方法}

$\mathrm{MFM}$ 観察には, SII ナノテクノロジー社製の環境制御型走査プ ローブ顕微鏡 SPA-300HV / SPI4000 を用いた. MFM 探針には, SII ナノテクノロジー社製 SI-MF40 を用いた. 探針の磁性体の材 料, 膜厚, 保磁力はそれぞれ CoPtCr, $50 \mathrm{~nm}, 200 \mathrm{Oe}$ であり， 磁化方向は垂直方向とした。この場合, MFM は試料面に垂直な 方向の磁場勾配を検出することとなり，面内記録媒体では記録磁

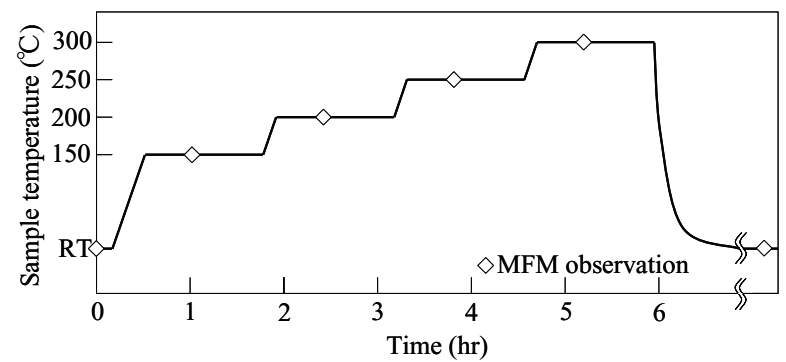

Fig. 1 Typical time-temperature program for MFM observation at elevated temperatures.
区の境界が明暗で現れる。一方，垂直記録媒体では記録磁区その ものが明暗で現れる. 試料の温度を冷却時は一 $50{ }^{\circ} \mathrm{C}$ 室温 $(\mathrm{RT})$ ， 加熱時はRT〜 $300{ }^{\circ} \mathrm{C}$ 範囲の一定温度で制御しながら磁気像の 観察を行った. 試料室内の真空度は, $8 \times 10^{-4} \sim 4 \times 10^{-5} \mathrm{~Pa}$ であつ た. 観察試料として，市販の面内記録方式のHDD と垂直記録方式 のHDDを用いた. 面内記録方式のHDDは最大面記録密度が約 80

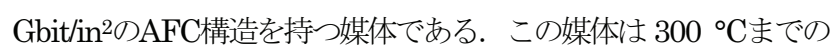
加熱サイクルによる磁気基本特性の変化はほとんどなかった. 垂 直記録方式のHDDは最大面記録密度が約 $110 \mathrm{Gbit} / \mathrm{in}^{2}$ であり, 垂

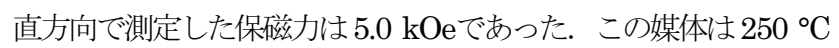
以下の温度への加熱処理ではM-H曲線はほとんど変化しなかった が, 300 C加熱では加熱処理によって保磁力が $4.4 \mathrm{kOe}$ に低下した. それぞれのHDDをPCに装着して, 面内磁気記録媒体にはランダ ムデータを，垂直磁気記録媒体には特定のビット配列を繰り返し 記録した.

試料加熱しながらその場観察を行った際の試料温度と時間経過 の例を Fig. 1 に示寸. RT で MFM 像を観察した後, 試料を昇温 速度 $6^{\circ} \mathrm{C} / \mathrm{min}$ で一定の温度に加熱した. 昇温直後は熱ドリフトに より試料が移動するため, 所定の温度に達してから 30〜60 分後に, MFM 像観察を開始した. この際，昇温前と同じ観察位置になる 様にステージ位置を調整し同一領域の観察を行った. 高温加熱後, 試料をRT まで自然冷却し同様の観察を行った.

\section{3. 実験結果}

\section{1 面内磁気記録媒体}

Fig. 2 に面内磁気記録媒体の温度を室温から $300{ }^{\circ} \mathrm{C}$ まで変化さ せて同一領域を MFM 観察した結果を示す. 観察領域は 7 トラッ ク（T-1〜T-7）であり，ランダムパターンが記録されている. $150{ }^{\circ} \mathrm{C}$ 加熱 (Fig. 2(b)) ではビット形状はRT とほとんど変わっ ていないが，短いビット長の信号が連続して記録された T-3 左側 などの領域ではコントラストが低下しているのが確認できる.こ の傾向は $200^{\circ} \mathrm{C}$ 加熱 (Fig. 2(c)) でも同様であるが, $250^{\circ} \mathrm{C}$ 加熱

(Fig. 2 (d)) になると短いビット長の信号が記録された部分では ビットに対応するコントラストがほとんど消失している領域が認 


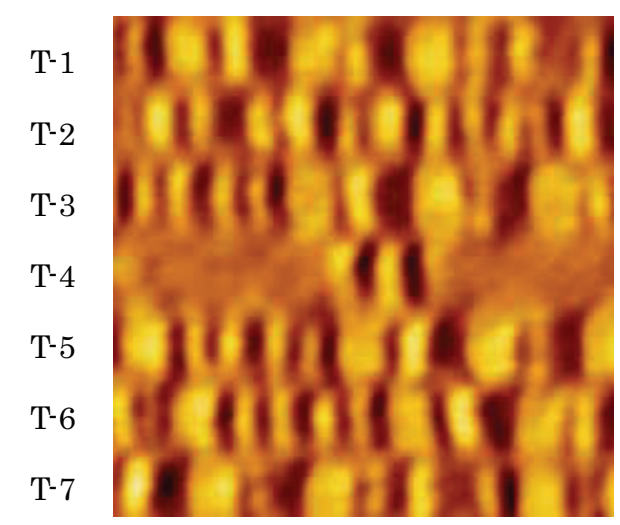

(a)

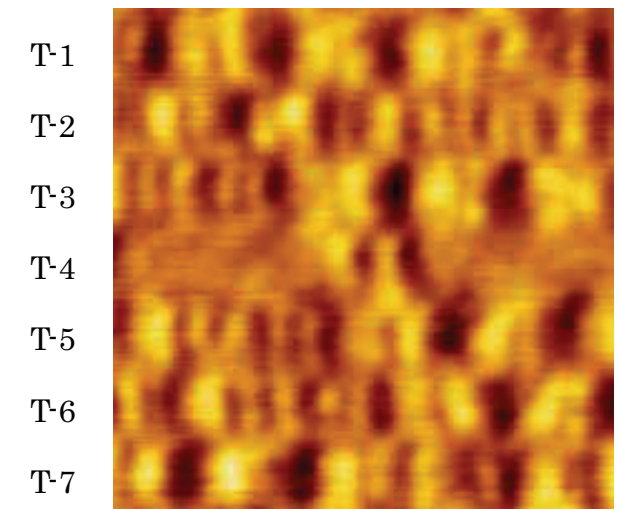

(d)

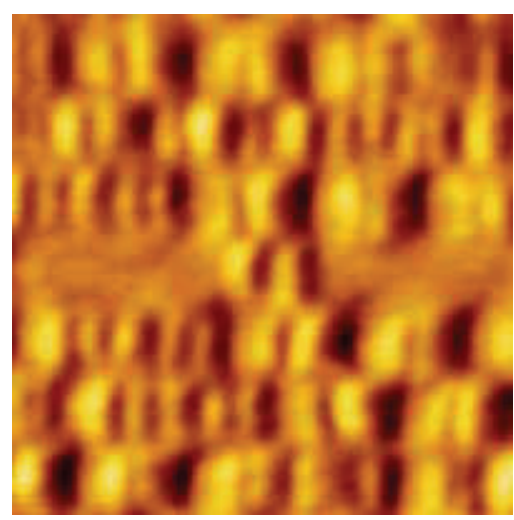

(b)

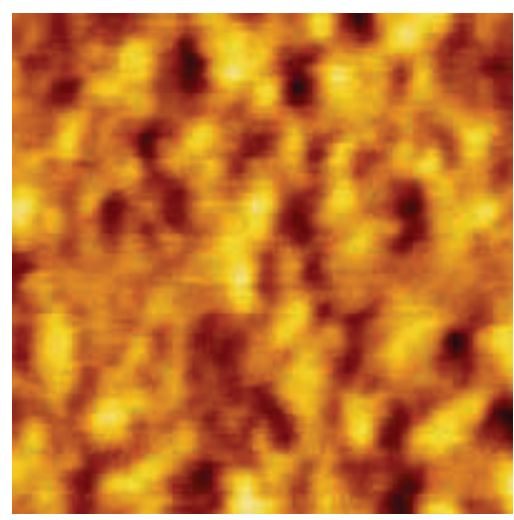

(e)

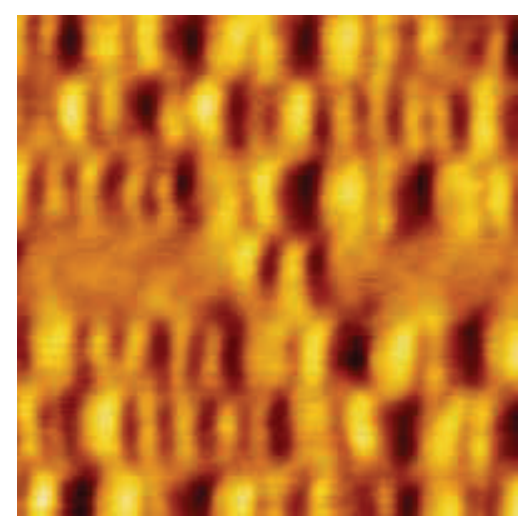

(c)

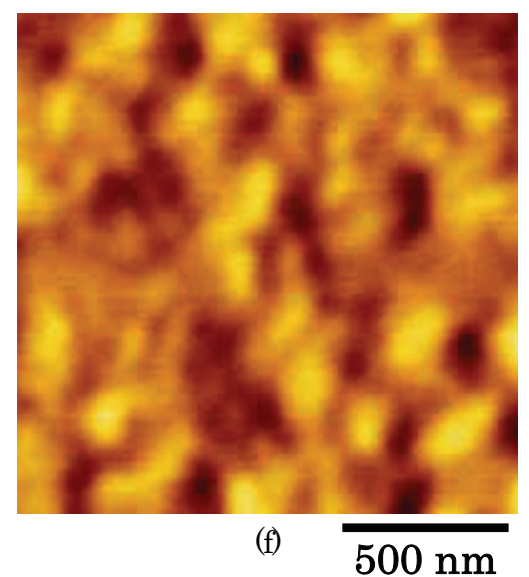

Fig. 2 MFM images of longitudinal recording media observed at (a) RT, (b) $150{ }^{\circ} \mathrm{C}$, (c) $200{ }^{\circ} \mathrm{C}$, (d) $250{ }^{\circ} \mathrm{C}$, (e) $300{ }^{\circ} \mathrm{C}$, and (f) $\mathrm{RT}$ after heating at $300^{\circ} \mathrm{C}$.

められる (T-6 中央).また長いビットではその形状が変化して隣 接ビットに浸食している傾向が認められる. $300^{\circ} \mathrm{C}$ 加熱 (Fig. $\left.2(\mathrm{e})\right)$ では短いビット長の信号が記録された部分ではそのコントラスト が完全に崩れており，記録信号の再生が困難な状態になっている ことが分かる．また長いビットは RT で観察した MFM 像と同位 置に存在しているのが確認できるが矩形性が大きく損なわれてい る. 隣接したトラック間で同じ磁化方向を持つビット同士が結合 しているような箇所も認められる. トラック間で磁気干渉による 磁化状態変化が生じているものと思われる. T-4 中央部に存在する 記録ビットの左右の長距離に及ぶ一方向記録のコントラストは, $\mathrm{RT}$ では一様にあるのに対し，加熱温度上昇とともに数十〜 100

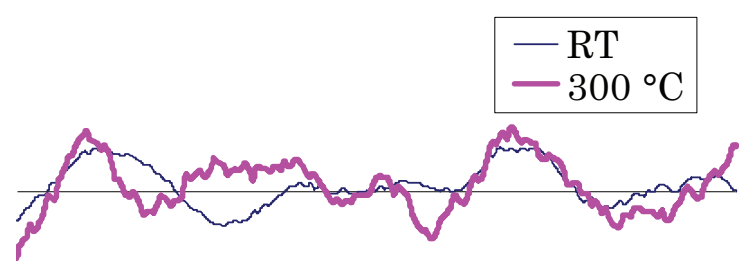

$\overline{100 \mathrm{~nm}}$

Fig. 3 MFM signal intensity variations of $\mathrm{T}-4$ observed at RT and $300{ }^{\circ} \mathrm{C}$. $\mathrm{nm}$ オーダの摇らぎが顕在化する傾向が認められる.この変化を可 視化するために MFM 像の T-4 左側におけるラインプロファイル を Fig. 3 に示し RT と $300{ }^{\circ} \mathrm{C}$ で比較する. ラインプロファイルで の縦軸の大小は, MFM 像における明暗に対応する. RT から $300{ }^{\circ} \mathrm{C}$ に加熱することで磁気コントラストに数十〜100 nm スケ 一ルの凹凸が生じ, 形状が変化していることが確認できる. これ は, 加熱に伴って一方向記録状態の熱緩和が起こり, 記録媒体の 微細構造に起因する磁気クラスター構造が観察され始めたものと 解釈することができる. 長矩の記録ビットが記録された領域でも, 加熱温度が上昇するにつれて数十〜100 nm オーダの摇らぎコン トラストが重なって観察される傾向が認められる. 記録状態の熱 緩和に伴って, 媒体の微細構造に起因する磁気クラスター構造が 顕在化しているものと思われる. $300{ }^{\circ} \mathrm{C}$ 加熱では比較的長いビッ トに対するコントラストは認められるが, 磁気クラスターを反映 すると思われる数十〜 $100 \mathrm{~nm}$ オーダの摇らぎが顕在化し, 短ビッ トに対するコントラストは完全に失われているのが分かる.この 媒体をRT まで泠却して観察した結果 (Fig. $2(\mathrm{f})$ ) は $300{ }^{\circ} \mathrm{C}$ で観 察した結果 (Fig. 2(e)) とほぼ等しい像となっている. $300{ }^{\circ} \mathrm{C} の$ 加熱によって不可逆な磁化状態の変化が生じたことが分かる.

加熱によって生じた変化を解析するために, MFM 像の T-3 のラ インプロファイルの加熱温度による変化を Fig. 4 に示す. これら のラインプロファイルは各トラックの中心線上で測定した MFM 信号強度の変化である. A で示した短いビット長の信号が連続し 
(a)

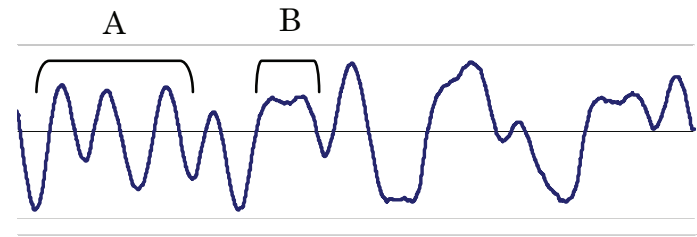

(b)

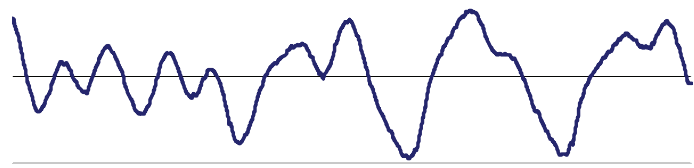

(c)

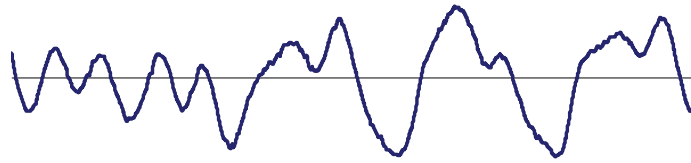

(d)

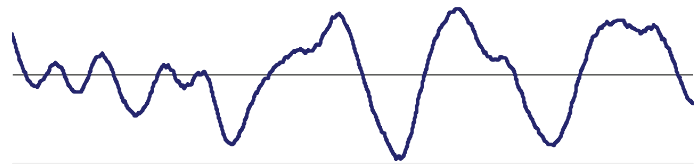

(e)

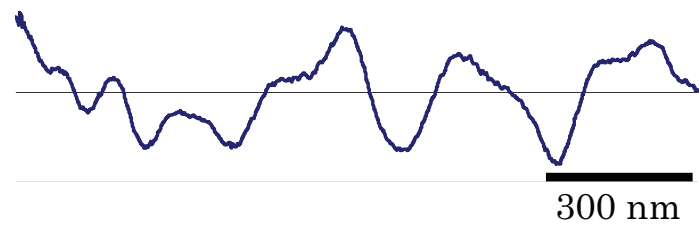

Fig. 4 MFM signal intensity variations of T-3 observed at (a) RT, (b) $150{ }^{\circ} \mathrm{C}$, (c) $200{ }^{\circ} \mathrm{C}$, (d) $250{ }^{\circ} \mathrm{C}$, and (e) $300{ }^{\circ} \mathrm{C}$.

て記録された領域では，温度上昇に従ってその波形の強度が低下 し，磁化状態の変化が他の領域より大きくなっていることが分か る. B は比較的長いビット長に対応する領域で, 台形状の信号波 形がRT て観察されている (Fig. 4(a))。これは探針の保磁力が十 分でなく，記録媒体の漏孔磁界の面内成分により探針の磁化が面 内方向に傾き，面内磁場勾配を検出していることが考えられる. この台形状のプロファイルが温度上昇に伴って狭くなっていく. これは長いビットでも, ビット境界近傍で磁化の緩和が起こって いることを示しているものと解釈される.

T-A

T-B

$\mathrm{T}-\mathrm{C}$

T-D

T-E

T-F

T-G

$\mathrm{T}-\mathrm{H}$

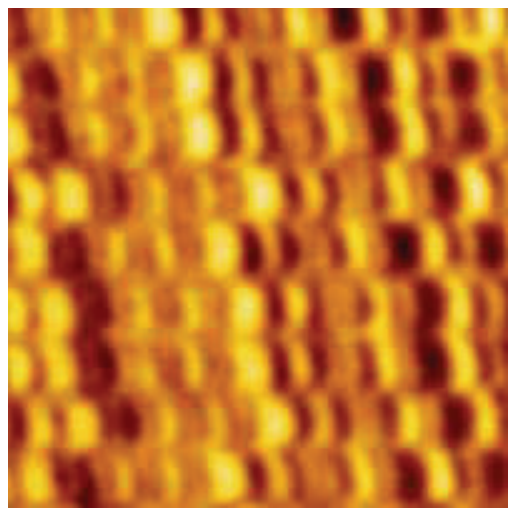

(a)

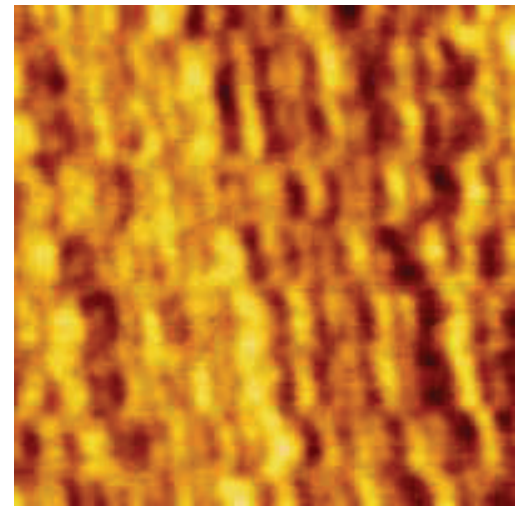

(b)

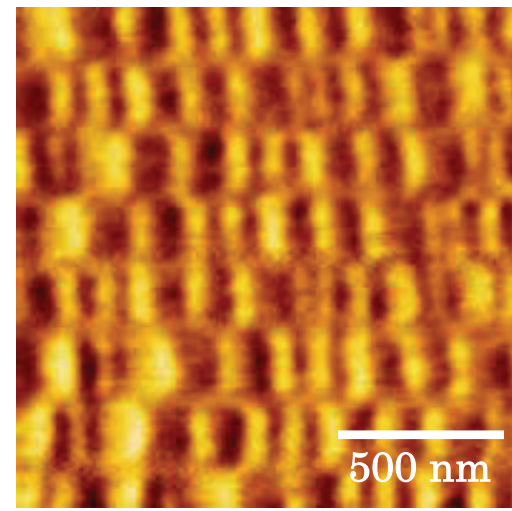

Fig. 5 MFM image of longitudinal recording media observed at $-50{ }^{\circ} \mathrm{C}$.

Fig. 5 に試料を一 $50^{\circ} \mathrm{C}$ に冷却して観察したMFM像を示寸. RT て観察したMFM像と比較すると, 冷却により記録磁化状態はほと んじ変化しなかったが，ビット境界の急峻性が増大しており，観 察分解能の向上効果が認められた. MFM観察時におけるカンチレ バーの温度が低くなり，熱ノイズが抑えられ分解能が向上した効 果が㗢いているものと思われる5。.

\section{2 垂直磁気記録媒体}

Fig. 6 に垂直磁気記録媒体の温度を変化させて同一領域を MFM 観察した結果を示寸. 観察領域は 8 トラック（T-A〜T-H） であり，全てのトラックで同じビット列が記録されているのが確 認できる. $200^{\circ} \mathrm{C}$ 加熱 (Fig. 6(b)) により, ビット形状が変化し, さらに $300{ }^{\circ} \mathrm{C}$ 加熱ではビット形状に対応するコントラストが失わ れることが分かった. $300{ }^{\circ} \mathrm{C}$ まで加熱してから RTまで泠却した 像（Fig. 6(c)）では, 観察領域内にビット列の存在は認められず, 磁気クラスターと思われる $20 \sim 40 \mathrm{~nm}$ 径の粒状の像が確忍できる.

MFM 像より 3 トラック（T-A，T-D，T-G）を選び，同様のビ ット列が記録されている部分の MFM 信号強度ラインプロファイ ルを Fig. 7 に示寸. Fig. 7(a)はRT, Fig. 7(b)は $200{ }^{\circ} \mathrm{C}$ で測定した ラインプロファイルである. RT で測定したラインプロファイルは 同様のビット列であることに対応して 3 トラックの波形は類似し ているが，A部などで若干の差異が認められる. $200{ }^{\circ} \mathrm{C}$ 加熱によ

Fig. 6 MFM images of perpendicular recording media observed at (a) RT, (b) $200{ }^{\circ} \mathrm{C}$, and (c) RT after heating at $300{ }^{\circ} \mathrm{C}$. 
T-A

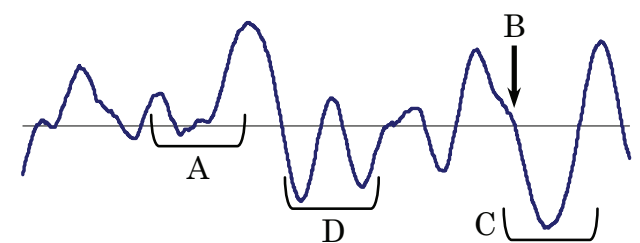

T-D

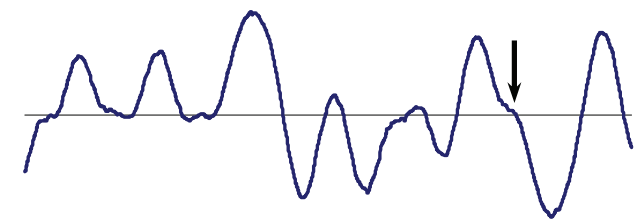

$\mathrm{T}-\mathrm{G}$

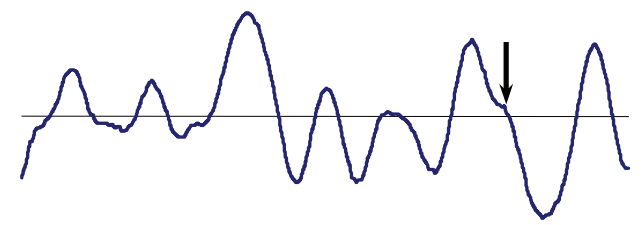

(a)

T-A

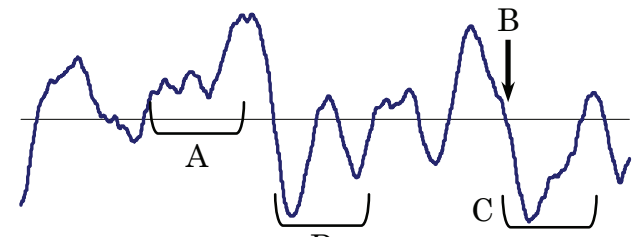

T-D

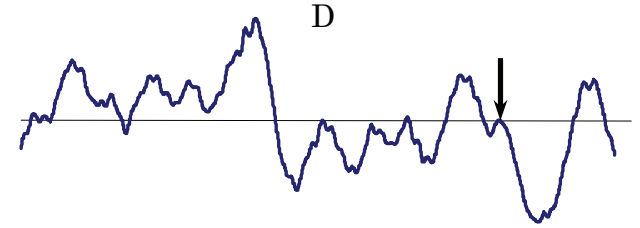

$\mathrm{T}-\mathrm{G}$

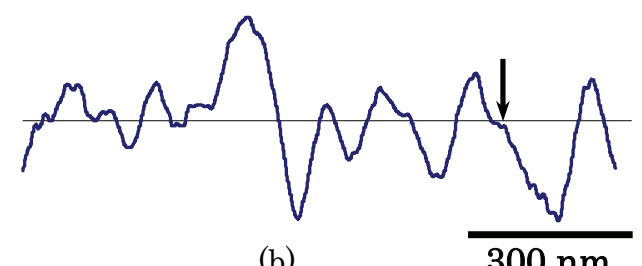

Fig. $7 \quad$ MFM signal intensity variations of perpendicular media observed at (a) RT and (b) $200^{\circ} \mathrm{C}$.

り，ラインプロファイルが RT の場合に比べて明膫に変化してい る. A 部では加熱によって波形の相対強度が明らかに低下し, 形 状も変化している．トラックが異なるとプロファイルの変化の様 子も違っていることが分かる. 例えば矢印 B で示寸部分では, RT では 3 トラックとも互いに類似ているが， $200^{\circ} \mathrm{C}$ 加熱ではその 形状がトラックごとに異なっている，この様な観察結果から，ビ ット形状の変化はビット配列が同一であっても必ずしも同様の変
化とならないことが分かる。記録媒体の微細構造や媒体を構成す る磁性結晶粒間の磁气的相互作用などがビットパターンの変化に 影響しているものと思われる.

特定のビット形状の変化に注目寸ると, C で示寸長いビットで は，加熱によりその波形が 3 トラックとも異なった変化をしてお り, ピーク位置がトラックによって数 $\mathrm{nm}$ 程度ずれていることが 分かる. これに対し D に示寸短いビットでは, その変化は長いビ ット $(\mathrm{C}$ 部) に比べて小さくなっている. 面内記録媒体において 長いビットではビット境界近傍から磁化が熱緩和していく傾向が 認められたが，垂直記録媒体ではビット中心部の形状が変化した 点で面内記録媒体の場合とは異なっていることが分かった。これ は，垂直記録媒体では面内記録媒体と異なり，磁化の緩和が必ず しもビット境界から始まらないことを示しているものと考えられ る.

\section{4. まとめ}

本研究では，面内記録方式及び垂直記録方式の HDD 媒体につ いて温度を制御しながら MFM 観察を行った。 その結果，いずれ の記録方式の媒体でも加熱することによって磁化状態の変化が認 められた，その傾向は，面内磁気記録媒体ではビット境界近傍か ら熱緩和が始まり，短いビット長が連続して記録された領域にお いて劣化が激しかった。これに対し，垂直磁気記録媒体ではビッ 卜中心部で熱緩和が起きる傾向が観察され，短いビットよりも長 いビットにおいて劣化が激しかった．また，同一ビット列であっ ても，トラックによって熱緩和の傾向は大きく異なる様子が観察 された。これは，媒体の微細構造が磁区構造の熱緩和に影響を 与えたものと考えられる.

謝辞＼cjkstart垂直磁気記録媒体の基本磁気特性の測定では，(株)日立製 作所中央研究所の平山義幸主任研究員に協力をいただきました. また本研究は文部科学省研究費（基礎研究C17560292）の補助を 受けて行ったものであり，ここに謝意を表します。

\section{References}

1) Y. Honda, Y. Hirayama, A. Kikukawa, and M. Futamoto: $J$. Magn. Soc. Jpn., 23, Suppl. S2, 49 (1999).

2) M. Futamoto, Y. Hirayama, N. Inaba, Y. Honda, K. Ito, A. Kikukawa, and T. Takeuchi: IEEE Trans. Magn., 35, 2802 (1999).

3) B. Bian, M. Avenell, J. Tsoi, L. Mei, S. Malhotra, and G. Bertero: IEEE Trans. Magn., 41, 648 (2005)

4) Y. Nakatani, N. Hayashi, Y. Uesaka, and H. Fukushima: IEEE Trans. Magn., 38, 2036 (2002).

5) H. Saito, R. Sunahara, Y. W. Rheem, and S. Ishio: IEEE Trans. Magn., 41, 4394 (2005).

2006 年 10 月 20 日受理, 2007 年 5 月 16 日採録 